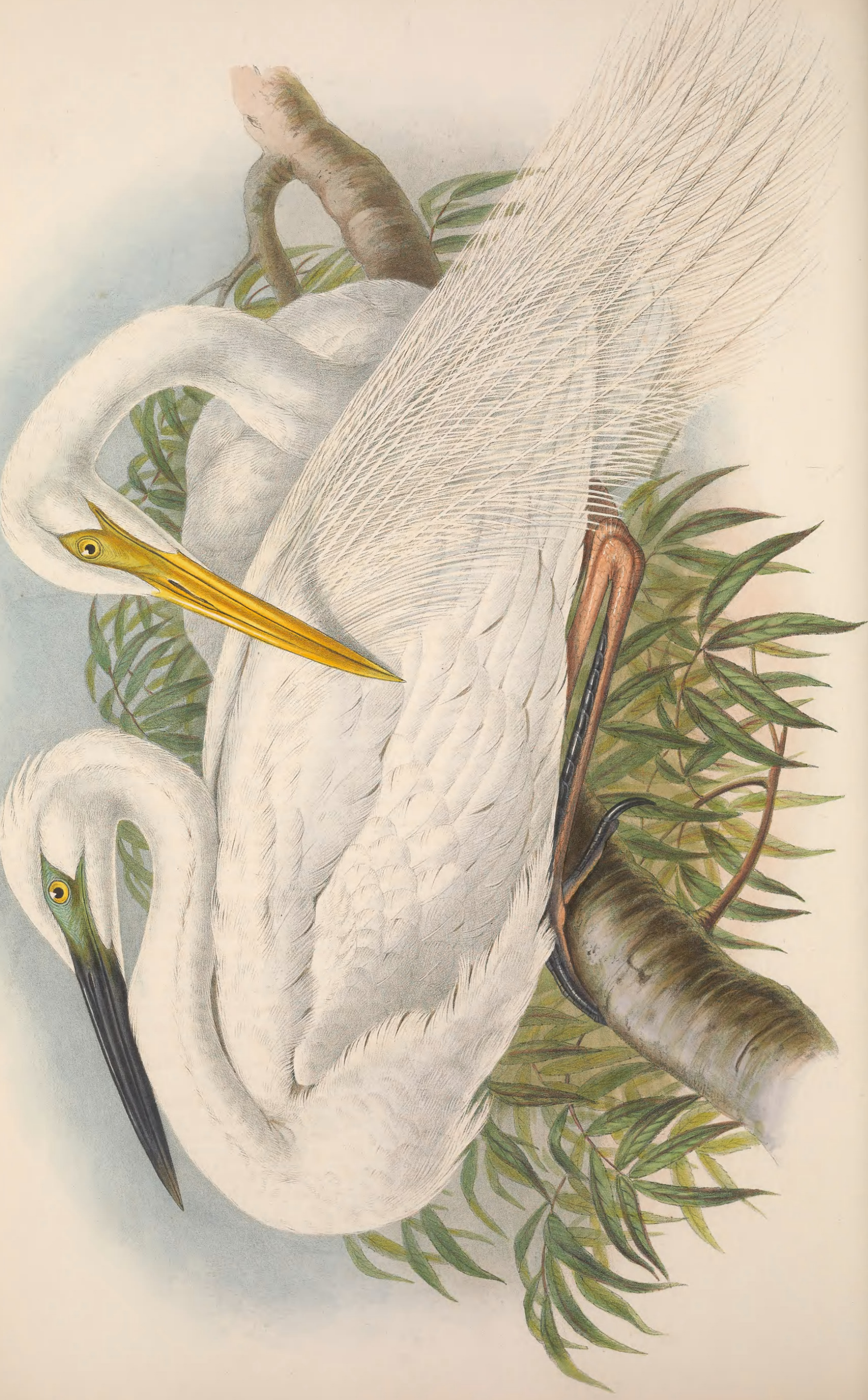




\title{
HERODIAS ALBA.
}

\section{Great White Egret or White Heron.}

\author{
Ardea alba, Linn. Faun. Suec., p. 59. \\ egretta, Temm. Man. d'Orn. (1815), p. 367. \\ egrettoïdes, S. G. Gmel. Reise, tom. ii. p. 193, tab. 24 . \\ modesta, J. E. Gray, Zool. Misc., p. 19. \\ flavirostris, Wagl. (Jerdon). \\ Erodius Victoria, Macgill. Man. Nat. Hist., Orn. vol. ii. p. 131. \\ albus, Macgill. ib. vol. ii. p. 134. \\ Herodias candida, Brehm, Vög. Deutschl., p. 584. \\ egretta, Boie, Isis, 1822, p. 559. \\ syrmatophorus, Gould, Birds of Australia, vol. vi. pl. 56 . \\ Egretta alba, Swains. Class. of Birds, vol. ii. p. 354.
}

There can be no doubt that the Herodias alba has just claims to a place in the avifauna of the British Islands. Willughby and Latham both regarded it in this light; and more recent writers, from Yarrell to Mr. Stevenson, have recorded instances of its occurrence in various parts of our country. Sir William Jardine states that during the winter of 1840-41 several White Herons were killed both in England and Scotland, and mentions that one was seen several times upon the shores of the Solway on the English side, above Port Carlisle; and Mr. Harting, in his 'Handbook of British Birds,' enumerates nearly twenty instances of its capture in other localities.

As regards the habits and economy of the bird, there has of course been but little opportunity for becoming acquainted with them in this country, the individuals that stray here from the neighbouring continent being usually permitted but a brief sojourn, its attractive appearance soon causing it to become a victim to the gunner, and to be added to the rarities of some local museum or private collection.

Ornithologists are still divided in opinion as to the range of the Herodias alba, whether it be universally dispersed, or if it be confined to the older portion of the globe. Some would restrict its limits to Europe, Asia, and Africa, and separate the Australian and New-Zealand birds as distinct-a view which I formerly entertained when I gave a figure of the species in the sixth volume of my folio work on the birds of Australia, though I rescinded it in my Hand-book. As regards the individuals which have visited Britain, there is no doubt that they were examples of one and the same species, a species which frequents the whole of the southern portions of Europe, Africa, from north to south, Asia Minor, India, and China. All Indian sportsmen and collectors speak of it as a bird of great beauty and of striking appearance, particularly just prior to the breeding-season, when its plumes are in their highest state of development.

The following brief notes have been kindly forwarded to me by my correspondents, to which I have appended some passages which have from time to time been published respecting the Great Egret.

Mr. Rodd, of Penzance, informed me on the 21st of November, 1870, that on one of the Scilly Islands, called Hedge-rock, there were frequently Common Herons, and that among them was seen a large white bird of a similar size, that it had been seen there more than once, and, after straying away for some time, returned again to the same islet with the Common Herons; as this individual was, so far as Mr. Rodd knew, never shot, it must not be included among the birds of Scilly; for it may have been a Spooubill, or a White Stork.

Charles Isham Strong, Esq., of Thorpe Hall, Peterborough, wrote on the 14th of November, 1872, to inform me that the Great White Heron in his collection was killed on Thorney Fen in Cambridgeshire (some ten miles distant), by a small farmer, who wished to have it preserved for himself, but, not liking the expense, sold it to a bird-stuffer at Peterborough, who resold it to Mr. Strong's father. This specimen, which has the ornamental plumes on the back, would appear to have been killed between the 1st of May and the 14th of July.

In Yarrell's ' History of British Brrds' (vol. ii. p. 456) it is stated that Messrs. Sheppard and Whitear, in their "Catalogue of the Norfolk and Suffolk Birds," published in the fifteenth volume of the "Transactions of the Linnean Society,' say :- "'On the 3rd of October, 1834, in a walk on the banks of the river Stour, we observed a large White Heron cross over from the Suffolk to the Essex side of the river. It appeared to be pure white, and to stand up rather taller than some Common Herons which were feeding not far off. A similar bird was observed in the spring on the Oakley shores; and subsequently to our observation, one was seen on the banks of the river Orwell." But the most valuable addition to our knowledge of the 
occurrence of this species in England was supplied by Mr. Arthur Strickland, in a communication made to the Natural-History Section of the British Association, at its meeting at Newcastle in August 1838, as published in the seventh volume of the Reports. Mr. Strickland stated that "this bird bad been unjustly excluded from the catalogue of occasional visitors to this country by late authors, as he could prove on unquestionable authority that it had been killed of late years in more cases than one. The first instance was twelve or thirteen years ago: a bird of this species was seen for some weeks about Hornsea Moor, in the East Riding of Yorkshire; it was some time after presented to the author, in whose collection it is at present, in perfect preservation. Another, in full summer plumage, was killed by a labourer in the fields of James Hall, Esq., of Scarbro, near Beverley, about three years ago, and is now in the possession of that gentleman. Another specimen of this bird is in the collection of Mr. Foljambe, of Osberton, with a label on the case stating it to have been killed near that place. A careful examination of these specimens will, Mr. Strickland has no doubt, prove that this bird is properly separated from the Large Egret of North America, which has been frequently placed in our collections for the British species. To these I may add a notice of one killed in Lincolnshire, but where the specimen is deposited I am not aware; and, lastly, Mr. Frederick Holme sent me the measurements of a specimen shot on the Isis, in Oxfordshire, in September 1833."

Yarrell goes on to state that this beautiful species was included in the Swedish fauna by Linnæus and Retzius, that it is an accidental visitor to Germany, France, Provence, Italy, Corsica, and Sardinia, and that it is common among the islands of the Grecian archipelago, Turkey, and Hungary. On the authority of H. E. Strickland, it frequents the salt marshes west of Smyrna; and Messrs. Dickson and Ross saw a few at Erzeroum, from the beginning of May till October. Mr. Stevenson, in his 'Birds of Norfolk, doubts whether the Great White Heron can be fairly included in the Norfolk list; still he states that Mr. Gurney possesses a fine specimen, purchased by him of the late Mr. Thurtell when that gentleman's birds were sold, and, on the authority of Mr. Joseph Clarke, of Saffron Walden, that Mr. Miller once found the wings of a Great White Heron near Yarmouth.

Having shown that the Great White Egret possesses numerous just claims to be enumerated among our accidental visitors, I give an additional note or two by some friends who have seen this bird on the Continent, which, together with quotations from the writings of Jerdon and a few lines from my 'Birds of Australia,' will close my account of this species.

"In Sicily," says Mr. Howard Saunders, "especially around Catania and Syracuse, this fine species is by no means uncommon. In Eastern Spain it is of occasional occurrence; but further west it becomes extremely rare - so much so that only a single example-came under my notice in the cotos de Donana, and my men, who were well acquainted with the smaller species ( $H$. egretta), were unable to give me any information respecting it. At Perpignan, just within the French frontier, Dr. Companyo has frequently obtained this species, and he assured me that it bred in the neighbouring marshes of Salces."

In Messrs Elwes and Buckley's "List of the Birds of Turkey" (Ibis, 1870, vol. vi. p. 333), these gentlemen state that the $H$. alba is "very common in the marshes of Macedonia, where we have seen as many as fourteen together. The great size and snowy plumage of this Heron make it a very conspicuous object among the tall reeds or when flapping slowly above them. We cannot say whether it breeds here; but in Bulgaria, though not so numerous, it certainly does. An old male, which was shot in February, had the long plumes of the back, which fall off in summer, fully developed."

Jerdon states (vide 'Birds of India,' vol. iii. p. 744) :- "The Large Egret is distributed throughout India to Ceylon, extending (if Gould's Syrmatophorus be rightly identified with this species) from Europe through most of Asia and Africa to Australia. It is of course abundant in the best-watered districts; but is found everywhere, feeding in rivers and tanks, and roosting on trees. It breeds in company on trees, often in or close to some village, making the usual nest of sticks, and laying three or four eggs of a bluish green colour."

Jerdon has remarked that Bonaparte created great confusion by separating the Egrets with yellow bills from those with black ones, not being aware that the colour of that organ changes with the season. During the period of nesting, the bill is more or less black; at other periods it is bright yellow.

Mr. Swinhoe speaks of the Herodias alba inhabiting the neighbourhood of Canton and other parts of China, although he questions the identity of the Chinese birds with those of Europe and India.

During my sojourn in Australia, I not unfrequently came upon a solitary individual of the Great White Egret, but in no instance did I obtain black-billed individuals.

The Plate represents both the summer and winter plumage, the figures being somewhat less than the natural size. 


\section{$2 \mathrm{BHL}$ Biodiversity Heritage Library}

Gould, John. 1873. "Great White Egret or White Heron, Herodias alba [PI. 22]." The birds of Great Britain 4, -. https://doi.org/10.5962/p.323981.

View This Item Online: https://www.biodiversitylibrary.org/item/221609

DOI: https://doi.org/10.5962/p.323981

Permalink: https://www.biodiversitylibrary.org/partpdf/323981

\section{Holding Institution}

Smithsonian Libraries

\section{Sponsored by}

Biodiversity Heritage Library

\section{Copyright \& Reuse}

Copyright Status: Public domain. The BHL considers that this work is no longer under copyright protection.

This document was created from content at the Biodiversity Heritage Library, the world's largest open access digital library for biodiversity literature and archives. Visit BHL at https://www.biodiversitylibrary.org. 